\title{
Wspieranie twórczego rozwoju dzieci pochodzących ze środowisk defaworyzowanych społecznie w wybranych kontekstach edukacji medialnej
}

\begin{abstract}
Michalina Kasprzak, Wspieranie twórczego rozwoju dzieci pochodzacych ze środowisk defaworyzowanych społecznie w wybranych kontekstach edukacji medialnej [Supporting the creative development of children from socially disfavoured backgrounds in selected contexts of media education]. Interdyscyplinarne Konteksty Pedagogiki Specjalnej, nr 23, Poznań 2018. Pp. 177-189. Adam Mickiewicz University Press. ISSN 2300-391X. DOI: https:// doi.org/10.14746/ikps.2018.23.03

The aim of the article is to present selected contexts of media education in supporting the creative development of children from disfavoured backgrounds. This analysis is based on the results of research carried out by the author in the framework of a doctoral dissertation at the day-support center in Poznan. In the final part of the article, the author presents proposals for changes concerning the introduction of media education elements' in day-support centers.
\end{abstract}

KEY WORDS: creative child development, socially disfavoured backgrounds, media education, non-formal education

\section{Wprowadzenie}

Od wielu lat media stanowią jeden z ważniejszych kanałów komunikacyjnych i informacyjnych. Rozpowszechnienie w XX w. środków masowego przekazu znacząco wpłynęło na przemiany kulturo- 
we, a obserwowany $\mathrm{w}$ ostatnich latach rozrost nowych technologii nieustannie je potęguje i oddziałuje także na ich charakter. Niewątpliwie współcześnie nowe media towarzyszą nam każdego dnia, w każdej z przestrzeni aktywności, którą podejmujemy. Dynamiczny rozwój nowych mediów nie powoduje jednak tak szybkich zmian w systemie edukacyjnym. Pomimo od dawna postulowanych potrzeb edukacji medialnej dotyczących wdrażania „nauczania o mediach, poprzez media i do mediów"1, sytuacja w polskich szkołach wciąż jest niepokojąca. Zainicjowane przez Krajową Radę Radiofonii i Telewizji (KRRiT) w 2000 r. zlecenie wykonania Raportu o stanie edukacji medialnej w Polsce ${ }^{2}$ zapoczątkowało $w$ niektórych szkołach wiele zmian dotyczących podążania za współczesnymi trendami wykorzystywania nowych technologii w pracy z dziećmi i młodzieżą, jednak wciąż istnieje szereg szkół, które nie realizowały i dotąd nie podejmują realizacji podstawowych celów edukacji medialnej.

Aczkolwiek szkoła nie jest jedynym środowiskiem wychowawczym, w którym funkcjonują dzieci i młodzież. Do najważniejszych środowisk wychowawczych poza szkołą zaliczyć można rodzinę, która jest podstawowym i naturalnym środowiskiem wychowawczym oraz środowisko lokalne ${ }^{3}$. Zatem rozwój człowieka (w kontekście wieloaspektowym) warunkowany jest przez wszystkie rodzaje środowisk, w których uczestniczy - zarówno za pośrednictwem wpływów zamierzonych, jak i niezamierzonych4. W związku z powyższym powstają nierówności społeczne, które są pochodnymi zmian cywilizacyjnych, kulturowych i postępu informacyjno-techno-

${ }^{1}$ W. Strykowski, M. Kąkolewicz, S. Ubermanowicz, Kompetencje nauczycieli edukacji medialnej, „Neodidagmata” 29/30, Wydawnictwo Naukowe UAM, Poznań 2008, s. 55.

2 J. Juszczyk-Rygałło, O potrzebie rewitalizacji edukacji medialnej, [w:] Pedagogika, red. K. Rędziński, M. Łapot, T. XXV, nr 2, Akademia im. Jana Długosza w Częstochowie, Częstochowa 2016, s. 135.

${ }^{3}$ W. Sroczyński, Szkice do pedagogiki środowiskowej, Wydawnictwo Uniwersytetu Przyrodniczo-Humanistycznego w Siedlcach, Siedlce 2016, s. 165-188.

${ }^{4}$ K. Segiet, "Wyjść poza zastane schematy”. Znaczenie edukacji i działań modyfikujacych środowisko życia człowieka, [w:] Animacja w środowisku. O potrzebie kreowania działań lokalnych (teoria a praktyka społeczna), red. K. Segiet, K. Słupska, A. Tokaj, Wydawnictwo Naukowe UAM, Poznań 2017, s. 49. 
logicznego, a ponadto powodują dystrybucję oraz reprodukcję kapitału środowiskowego i społeczno-kulturowego. W środowiskach defaworyzowanych społecznie, a więc społecznie nieuprzywilejowanych, w których nierówności powstają ze względu na zaniżone szanse jednostki z danej grupy względem korzystania z praw i przywilejów, które przysługują każdemu człowiekowi ${ }^{5}$ (m.in. są to: rodziny zagrożone marginalizacją lub wykluczeniem społecznym, pochodzące $z$ grup etnicznych czy narodowościowych, rodziny, w których dzieci mają problemy szkolne lub rówieśnicze) z większym natężeniem widoczne są problemy wynikające głównie z zaburzonego funkcjonowania środowiska rodzinnego czy szkolnego. Uwypuklają się więc tezy dotyczące kryzysów współczesnej rodziny czy systemów edukacyjnych, w konsekwencji czego zauważalna jest wiodąca rola środków masowego przekazu i nowych technologii w codziennym życiu (zwłaszcza młodego pokolenia). Wszechobecność mediów zauważalna jest we wszystkich sferach życia: we wspomnianym wcześniej systemie edukacji, w systemie rodzinnym czy politycznym, w życiu publicznym, a ponadto podczas nauki, pracy czy wypoczynku. Ma to znaczący wpływ na zmieniający się styl życia, systemy wartości i wzory zachowań coraz to młodszych pokoleń6 ${ }^{6}$ W związku z powyższym w ostatnich latach „postuluje się jednocześnie opracowanie ogólnokrajowego programu formalnej (system oświaty) i nieformalnej (środowisko rodzinne, instytucje kultury, organizacje pozarządowe) edukacji medialnej obejmującej wszystkie grupy społeczne i wiekowe, ze szczególnym uwzględnieniem dzieci i młodzieży"7.

${ }^{5}$ A. Zbonikowski, Społeczne oddziaływania defaworyzujace a poczucie własnej wartości dzieci i młodzieży, [w:] Psychospołeczne uwarunkowania defaworyzacji dzieci i młodzie$\dot{z} y$, red. K. Hirszel, R. Szczepanik, A. Zbonikowski, D. Modrzejewska, Wydawnictwo Difin SA, Warszawa 2010, s. 13.

${ }^{6}$ E. Wysocka, Zagrożenia społeczno-kulturowe dla rozwoju młodego pokolenia, [w:] Dzieci i młodzież w niegościnnym świecie. Zagrożenia rozwojowe $i$ społeczne, red. E. Wysocka, Wydawnictwo Akademickie Żak, Warszawa 2012, s. 107.

7 J. Juszczyk-Rygałło, O potrzebie rewitalizacji edukacji medialnej, [w:] Pedagogika, red. K. Rędziński, M. Łapot, T. XXV, nr 2, Akademia im. Jana Długosza w Częstochowie, Częstochowa 2016, s. 136. 


\section{Edukacja medialna a twórczy rozwój dziecka}

Potencjał twórczy posiada każdy człowiek, a nie wyłącznie osoby uzdolnione czy zdolne. Jednak jego rozwój (zwłaszcza w okresie dzieciństwa) uwarunkowany jest przez osoby dorosłe (rodziców, opiekunów, nauczycieli), którzy powinni zachęcać i stwarzać przestrzeń do podejmowania twórczego myślenia i twórczej działalności dziecka ${ }^{8}$. Dzieci pochodzące ze środowisk defaworyzowanych społecznie rzadko doświadczają tego typu wsparcia w domu rodzinnym. Ponadto współcześnie należy pamiętać, że twórczy rozwój dotyczy też sfery medialnej czy hipermedialnej. Szkoła wydaje się być pierwszym ze środowisk (zaraz po środowisku rodzinnym), gdzie dziecko powinno otrzymać stosowne wsparcie w tym zakresie. Zatem współczesny nauczyciel stoi przed wieloma wyzwaniami, które tworzą m.in. zmiany społeczno-kulturowe. Powinien on nie tylko być profesjonalistą, podążać za nowymi trendami nauki i aktualizować oraz rozwijać swoje kompetencje, lecz przede wszystkim, wychowując młodego człowieka, musi być pedagogiem refleksyjnym, który weźmie pod uwagę wszystkie dziedziny, w których współczesne dzieci i młodzież funkcjonują. Jego rola nie dotyczy bowiem wyłącznie przekazywania wiedzy, ale także kształtowania się osobowości uczniów, ich tożsamości, pragnień, celów i marzeñ . Niestety, sytuacja w polskim środowisku edukacyjnym nie wykazuje znacząco pozytywnych prognoz na szybką zmianę sytuacji w szkołach. Przykładem mogą być m.in. badania Anny Michniuk dotyczące współczesnej - nowomedialnej szkoły ${ }^{10}$ czy Danuty Mo-

${ }^{8}$ M.A. Runco, To understand is to create: an epistemological perspective on human nature and personal creativity, [w:] Everyday creativity and New views of human nature. Psychological, social, and spiritual perspectives, red. R. Richards, American Psychological Association, Washington 2007, s. 91-107.

${ }^{9}$ I. Żeber-Dzikowska, Teacher's and student's creativity as a challenge for the modern education, [w:] Pedagogika, red. K. Rędziński, M. Łapot, T. XXV, nr 2, Akademia im. Jana Długosza w Częstochowie, Częstochowa 2016, s. 37.

${ }^{10}$ A. Michniuk, Wspótczesna, nowomedialna(?) szkoła - próba charakterystyki, [w:] Edukacyjne i społeczne wyzwania rzeczywistości cyfrowej, red. A. Iwanicka, Wydawnictwo Naukowe UAM, Poznań 2007, s. 101-123. 
rańskiej, koncentrujących się na zastosowaniu nowoczesnych metod kształcenia i technologii informacyjnej podczas lekcji11. W obu przypadkach autorki deklarują, że owszem - istnieją szkoły unowocześnione, które mają chętną kadrę i bogatą strefę materialną w zakresie nauczania z wykorzystaniem nowych mediów (także do twórczego rozwoju ucznia), jednak wciąż stanowią one mniejszość względem szkół, które z różnych przyczyn nie wprowadzają koniecznych zmian w procesie nauczania i uczenia się. Tymczasem główne idee edukacji medialnej (wspomniane na samym wstępie) koncentrują się nie tylko na rozwijaniu wiedzy o mediach i ich oddziaływaniu czy wprowadzaniu w kulturę mediów, ale także na zdobywaniu nowych wiadomości i umiejętności oraz ich wykorzystaniu w praktyce $^{12}$. A zatem sama umiejętność obsługi sprzętu (co często wymieniane jest przez nauczycieli jako bariera w stosowaniu nowych mediów podczas zajęć, w kontekście kompetencji medialnych współczesnego nauczyciela vs. ucznia - gdyż w opinii nauczycieli to uczniowie mają wyższe kompetencje $w$ tym zakresie ${ }^{13}$ ) nie jest wystarczająca i niekoniecznie znajomość ta prowadzi do twórczej aktywności młodego człowieka.

Inną kwestią jest edukacja i wspieranie do twórczości w młodszym wieku dziecka. Należy zaznaczyć, że dzieci w coraz młodszym wieku mają kontakt z nowymi technologiami informacyjnymi na zróżnicowanym poziomie. Współcześnie małe dzieci (od ok. 3. roku życia) korzystają z nowych mediów zwykle w domu rodzinnym, a później - w wieku przedszkolnym już także poza domem, (jeżeli w przedszkolu stosowane są nowoczesne metody i techniki pracy). Nie powinna więc dziwić biegłość w obsłudze nowych mediów przez dzieci także na późniejszych etapach edukacyjnych. Poza tym używanie mediów w tak wczesnym wieku jest powiązane ze zmia-

11 D. Morańska, Nauczyciel wobec wyzwań społeczeństwa informacyjnego, [w:] Edukacyjne i społeczne wyzwania rzeczywistości cyfrowej, red. A. Iwanicka, Wydawnictwo Naukowe UAM, Poznań 2007, s. 47-56.

12 A. Ogonowska, Wspótczesna edukacja medialna: teoria i rzeczywistość, Wydawnictwo Naukowe Uniwersytetu Pedagogicznego, Kraków 2013, s. 31.

13 Por. A. Michniuk, op. cit., s. 104. 
nami zachodzącymi w funkcjonowaniu poznawczym, fizycznym, motorycznym, a także społecznym i emocjonalnym dzieci, który ponadto jest bardzo zdynamizowany ${ }^{14}$. W sytuacji, gdy edukacja medialna nie jest wdrażana w procesie kształcenia lub prowadzona jest nieprawidłowo (w przedszkolu, szkole czy wśród osób dorosłych), z dobrowolnego uczestnictwa w świecie medialnym mogą wynikać widoczne negatywne skutki i/lub zagrażające rozwoju jednostki, dotyczące np. nieumiejętnego wyboru komunikatów i treści medialnych, niewykorzystywania potencjału materiałów multimedialnych i hipermedialnych oraz narzędzi medialnych. W najnowszym, raporcie EU Kids Online 2018 (pełny raport ukazał się w grudniu 2018 r.), przygotowywanym pod kierunkiem Jacka Pyżalskiego w partnerstwie z Fundacją Orange, opracowanym na reprezentatywnej grupie 1300 osób w wieku 9-17 lat, zespół badaczy przedstawia następujące wnioski:

wielu uczniów nie zetknęło się $\mathrm{w}$ szkole z zasadami poruszania się po sieci. 1/3 wskazuje, że nauczyciele w szkole nigdy lub prawie nigdy nie zajmują się kwestią bezpieczeństwa online. Aż 40\% uczniów stwierdza, że w szkole nie ma ustalonych zasad korzystania z interne$\mathrm{tu}, \mathrm{a} 45 \%$ badanych nigdy nie rozmawiało $\mathrm{z}$ nauczycielami o tym, jakie są dobre zwyczaje postępowania w sieci ${ }^{15}$.

A zatem inną kwestią niedostatku lub braku edukacji medialnej w życiu młodego pokolenia jest rozpowszechniająca się przemoc w sieci, o bardzo zróżnicowanym poziomie natężenia i wielu jej rodzajach ${ }^{16}$, co może prowadzić do podejmowania zachowań ryzy-

14 M. Klichowski, J. Pyżalski, K. Kuszak, A. Klichowska, Jak technologie informacyjno-komunikacyjne moga wspierać rozwój dziecka w wieku przedszkolnym? - studium teoretyczne, [w:] Małe dzieci w świecie technologii informacyjno-komunikacyjnych - pomiędzy utopijnymi szansami a przesadzonymi zagrożeniami, red. J. Pyżalski, Wydawnictwo Naukowe UAM, Poznań 2017, s. 116.

${ }^{15}$ https:/ / fundacja.orange.pl/aktualnosci/artykul/90-proc-nastolatkow-nieumie-tworczo-korzystac-z-technologii/ [dostęp: 24.09.2018].

16 J. Pyżalski, Agresja elektroniczna i cyberbullying jako nowe ryzykowne zachowania młodziė̇y, Oficyna Wydawnicza „Impuls”, Kraków 2012. 
kownych zagrażających nie tylko rozwojowi, ale także życiu dzieci i młodzieży.

Kolejnym obszarem, który dla dzieci pochodzących ze środowisk defaworyzowanych społecznie ma szczególne znaczenie w kontekście rozwoju twórczego i kompetencji medialnych, jest środowisko lokalne. Kiedy dziecko nie doświadcza wsparcia w domu rodzinnym czy w szkole lub gdy wsparcie jest prowadzone tam niedostatecznie, często ostatnim miejscem $\mathrm{w}$ najbliższym otoczeniu dziecka są instytucje wsparcia dziennego prowadzone w środowisku lokalnym. W Polsce placówki te świadczą pomoc bezpłatnie w zakresie wspierania rodzin $w$ wypełnianiu funkcji rodziny, a ich systematycznie prowadzone działania (np. codzienne, dwa razy w tygodniu itp.) skierowane są głównie do dzieci i młodzieży doświadczających niekorzystnej (ekonomicznie, społecznie i kulturowo) sytuacji w domu rodzinnym oraz posiadających niepowodzenia edukacyjne i szkolne. W tego typu instytucjach (są to m.in.: świetlice środowiskowe, socjoterapeutyczne, terapeutyczne, forma podwórkowa, kluby, centra lub ogniska dla dzieci i młodzieży), działania zorientowane są głównie na prowadzeniu zajęć, które pozwolą na wzmocnienie szans edukacyjnych dzieci i młodzieży pochodzących ze środowisk nieuprzywilejowanych, wyrównanie wiedzy lub jej kompensację w danym zakresie ${ }^{17}$.

W badaniach własnych, przeprowadzonych przez autorkę w ramach dysertacji doktorskiej dotyczącej twórczości dzieci defaworyzowanych społecznie w lokalnych formach wsparcia i opieki w studium porównawczym, poruszono wiele kwestii edukacyjnych, w znacznie szerszym kontekście. Na potrzeby niniejszego artykułu autorka wybrała do prezentacji fragment badań, który dotyczy wyłącznie kwestii edukacji medialnej. Badania miały charakter jakościowo-ilościowy i zostały przeprowadzone metodą studium przypadku w instytucji z Poznania. Podczas badań wykorzystano technikę obserwacji, wywiadu kwestionariuszowego oraz prac rysunkowych dzieci z rozmową na ich temat.

17 Ustawa z dnia 9 czerwca 2011 r. o wspieraniu rodziny i systemie pieczy zastępczej, Dz.U. z 2013 r., poz. 135, z późn. zm., art. 24. 
Zajęcia w grupie młodszej, 6-12 lat odbywały się w poniedziałki i środy, po 4,5 h zegarowej. W każdą środę dzieci miały do dyspozycji teoretycznie 5 komputerów z dostępem do internetu (z czego działały 3) i 15 minut z przeznaczeniem na gry. W grupie było maksymalnie 12 dzieci (uczestnictwo $w$ zajęciach $w$ tego typu instytucjach jest dobrowolne). W każdą środę było więcej uczestników zajęć od $15 \%$ do $20 \%$ niż w poniedziałek. Zauważalne były również punktualność i entuzjazm spowodowany czasem wolnym przy komputerach. System korzystania z komputerów odbywał się zmianowo (po 15 minut 1 osoba), w myśl zasady „kto pierwszy ten lepszy", a ponadto "kto ma zadanie domowe, najpierw musi je odrobić". Pozostali uczestnicy mogli ten czas wolny spożytkować na zabawę. W praktyce wyglądało to tak, że maksymalnie czworo dzieci odrabiała zadanie domowe, a pozostałe osoby siedziały przy komputerach, mimo że użytkowały je troje (reszta oglądała i dopingowała kolegów i koleżanki w grach, później następowała zamiana). Podczas wszystkich zajęć żadne dziecko nie zrezygnowało z możliwości gry na komputerze. Najczęściej większość dzieci wybierało gry zręcznościowe (92\% dzieci), natomiast mniejszość gry logiczne $(8 \%)$. Było to zgodne z zasadami obowiązującymi $w$ instytucji, dozwolone były tylko gry z puli edukacyjnych. Przez cały czas trwania obserwacji (trzy miesiące) nikt nie zainteresował się nawet naprawą pozostałych komputerów. Nie odbywały się żadne zajęcia edukacyjne z zakresu zajęć medialnych (także bez użycia sprzętu).

$\mathrm{W}$ trakcie wywiadów $\mathrm{z}$ wychowawcami (cztery osoby) w danej instytucji zgodnie doszli oni do wniosku, że zajęcia komputerowe, informatyczne i medialne (czy szerzej zajęcia wykorzystujące nowe technologie) nie są prowadzone $\mathrm{w}$ ich instytucji (choć jeden $\mathrm{z}$ wychowawców był absolwentem studiów informatycznych - tytuł zawodowy magistra). Wszyscy wychowawcy byli czynnymi nauczycielami $\mathrm{w}$ publicznych szkołach podstawowych. Ponadto $\mathrm{z}$ deklaracji wychowawców wynika, że nie uważają oni tego typu zajęć za rozwijających twórczość dzieci. W jednej z opinii wychowawca zauważył, że: „te nowe media raczej przeszkadzają w edukacji tym dzieciom, jak tylko są komputery w środy, to trudno im się skupić 
na czymś innym. Oni pochodzą często z trudnych środowisk, czworo $\mathrm{z}$ nich nie ma dostępu do komputera $\mathrm{w}$ domu, ale przynajmniej jeden z rodziców każdego dziecka ma smartfon. Przy czym ze smartfonu nie wydrukują im pracy domowej, a nasza drukarka często się psuje. Dzieci wpadają z jednego wora do drugiego - bo jak nie masz pracy domowej, to $\mathrm{w}$ szkole albo dostajesz punkty ujemne, albo uwagę do dzienniczka". Inny wychowawca w odpowiedzi na system zmianowy przy komputerach obowiązujący w instytucji odpowiedział: "gdyby dzieci nie znały reguł, najlepiej całe zajęcia siedziały by przy komputerach i grały w gry, a my staramy się im pokazywać, że te gry to nie wszystko. Mamy plan na ten wspólny czas. Poza tym mamy dużo planszówek, więc - zwłaszcza tym osobom oglądającym - proponujemy wspólne rozgrywki. Czasami udaje się kogoś przekonać".

Jednak w odpowiedzi na pytanie, czy wychowawcy wyobrażają sobie współczesny świat bez użycia nowych mediów, zgodnie odpowiedzieli przecząco. W argumentacji jednak odwoływali się do tego, że „tym dzieciom jest to teraz niepotrzebne, ważniejsze są inne potrzeby, które trzeba im zapewnić, bo nie wszystkie dzieci otrzymują w domu ciepły posiłek".

W przypadku zajęć wspierających wieloaspektowy rozwój dzieci, wychowawcy korzystali głównie z oferty zajęć przedmiotowych (a dokładnie z przedmiotów, z którymi dzieci miały największe problemy w szkole: matematyka, język polski i język angielski). Zajęcia dotyczące wspierania twórczości dziecka utożsamiane były przez wszystkich wychowawców z zajęciami artystycznymi. Jeden z wychowawców zadeklarował „,jestem opiekunem kółka plastycznego u mnie w szkole, sam lubię takie rzeczy robić, często pracujemy tak twórczo z dziećmi tutaj. Przynoszę materiały, opisuję im, co to jest, a potem robimy. To zawsze jest miło spędzony czas. Dzieci często mnie pytają, co zrobić, czego użyć, jaki kolor wybrać, sugeruję im i podpowiadam, bo trochę ich już znam i wiem co lubią. Ostatnio robiliśmy ozdobne pudełka techniką decoupage na prezenty dla bliskich. Przed świętami często robimy kartki świąteczne, które idą do naszych sponsorów, wtedy wybieramy te najładniej- 
sze". Jeden z wychowawców zauważył, że "niektóre dzieci mają kreatywne pomysły, np. podczas podwieczorków zawsze sobie dyskutujemy na bieżące tematy albo zadaję jakieś pytanie. Dzieci mają taką wyobraźnię, że zawsze jest wesoło".

Podsumowując, należy odwołać się do faktu, iż wychowawcy w kontekście wiary w możliwości i szanse edukacyjne dzieci pochodzących ze środowisk defaworyzowanych społecznie koncentrują się raczej na zapewnieniu im podstawowych potrzeb życiowych, omijając całkowicie fakt obecności nowych mediów w codziennym życiu. W myśleniu o rozwoju dzieci i ich potencjale odwołują się do zasad reprodukcji społecznej, kulturowej i ekonomicznej (w myśl teorii Karola Marksa polegających na kopiowaniu wzorców z najbliższego otocznia), Badani wychowawcy nie dostrzegają $w$ technologiach informacyjno-komunikacyjnych potencjału edukacyjnego, sprzyjającego rozwijaniu kreatywności i wyrażaniu własnego ja. Nie interpretują ich jako narzędzi pomocnych w kształtowaniu własnej tożsamości i kontaktów społecznych czy wzmacniania udziału w życiu społecznym, mimo że sami zauważają, że nie wyobrażają sobie współczesnego życia bez nowych technologii. Jednak należy zauważyć, że dzieci uczęszczające do instytucji wsparcia dziennego są przez wychowawców traktowane jako "potrójnie defaworyzowani", gdyż pochodzą z nieuprzywilejowanych środowisk, w większości nie mają sprzętu, możliwości i kompetencji wykorzystania mediów np. w procesie twórczym, a ponadto wychowawcy nie dają im nawet szansy zmiany myślenia o swojej przyszłości na inną, jak naśladowanie wzorców rodzinnych.

Czas spożytkowany na grach w świetlicy nie rozwija kompetencji twórczych ani medialnych dzieci, być może dostarcza rozrywki, której dzieci ze środowisk defaworyzowanych społecznie $\mathrm{w}$ tym zakresie doświadczają rzadziej niż ich rówieśnicy. Jednak, jak zauważają autorzy we wspomnianych wcześniej wnioskach z raportu EU Kids Online 2018 dotyczących dzieci i nastolatków w Polsce: „90 proc. nastolatków nie umie twórczo korzystać z technologii"18,

${ }^{18}$ https:/ / fundacja.orange.pl/aktualnosci/artykul/90-proc-nastolatkow-nie-umie- 
„najczęstsze aktywności online to konsumpcja treści - oglądanie wideo i słuchanie muzyki, a także komunikowanie się z bliskimi. Ponad $80 \%$ badanych mówi, że skorzystało z takiej możliwości przynajmniej raz w ciągu ostatniego miesiąca"19. W związku z powyższym aktywność biernego uczestnictwa $\mathrm{w}$ sieci praktykowana przez dzieci i młodzież i niewykorzystywanie potencjału, które wprowadzają technologie do naszego codziennego życia nie dotyczy wyłącznie dzieci pochodzących ze środowisk defaworyzowanych społecznie. Niniejszy raport tylko potwierdza, że konieczne jest natychmiastowe wprowadzenie zmian $\mathrm{w}$ systemie edukacyjnym, a sama edukacja medialna powinna stanowić jeden z ważniejszych elementów nowego programu, gdyż młodzi ludzie potrzebują osób dorosłych, którzy będą towarzyszyć im w odkrywaniu dotąd nie znanych obszarów wiedzy.

\section{Zamiast zakończenia}

Konkludując, instytucje wsparcia dziennego odgrywają ważną rolę $\mathrm{w}$ życiu dzieci i młodzieży pochodzących ze środowisk defaworyzowanych społecznie. Jednak kierownicy i wychowawcy tam pracujący powinni zaktualizować ofertę zajęć, jednocześnie ją unowocześniając. Zazwyczaj instytucje te nie mają dużych zasobów finansowych, aczkolwiek mogą przygotowywać projekty i brać udział w konkursach organizowanych przez Unię Europejską lub instytucje w kraju. Ponadto można zaprosić do współpracy z instytucją firmy zewnętrzne, które przekażą sprzęt do pracy z dziećmi.

Najważniejsze jednak są chęci do zmiany i aktualizacji zarówno wiedzy na temat postrzegania twórczości, jak i mediów przez samych wychowawców. Jeżeli pogląd reprodukcji będzie hamował nawet myślenie wychowawców o szansie rozwoju dzieci i młodzieży pochodzących ze środowisk defaworyzowanych społecznie

tworczo-korzystac-z-technologii/ [dostęp: 24.09.2018].

${ }^{19}$ Ibidem. 
na podejmowanie innych działań, lepszych wzorców zachowań i zmianę swojej sytuacji na lepsze - to nawet doskonale usprzętowiona instytucja nie będzie dostarczała owocnych efektów.

Poza tym wprowadzenie zajęć z zakresu edukacji medialnej nie zawsze wymaga obecności sprzętu i osób o wysokich kwalifikacjach. Wystarczy odrobina zaangażowania, poszerzenie wiedzy z danego zakresu i postawa otwartości. Zaangażowanie ze strony wychowawcy w zdobycie nowych kompetencji - np. dotyczących teoretycznych zagadnień medialnych tj. cyberbulling czy hejt $\mathrm{w}$ sieci, ale także w zakresie wdrażania programów „programowanie na dywanie" czy nawet zaproszenie osoby z zewnątrz do przeprowadzenia warsztatów dla dzieci np. z narzędzi medialnych, które przydatne będą im do nauki. Z pewnością spowoduje to wzrost atrakcyjności zajęć, ale także może przyczynić się do faktycznej zmiany w życiu tych młodych ludzi, którzy i tak przez wiele osób (również z najbliższego otoczenia dziecka) ze względu na pochodzenie ze środowiska defaworyzowanego społecznie skazane są na „porażkę".

\section{Bibliografia}

Juszczyk-Rygałło J., O potrzebie rewitalizacji edukacji medialnej, [w:] Pedagogika, red. K. Rędziński, M. Łapot, T. XXV, nr 2, Akademia im. Jana Długosza w Częstochowie, Częstochowa 2016, s. 131-143.

Klichowski M., Pyżalski J., Kuszak K., Klichowska A., Jak technologie informacyjnokomunikacyjne moga wspierać rozwój dziecka w wieku przedszkolnym? - studium teoretyczne, [w:] Małe dzieci w świecie technologii informacyjno-komunikacyjnych - pomiędzy utopijnymi szansami a przesadzonymi zagrożeniami, red. J. Pyżalski, Wydawnictwo Naukowe UAM, Poznań 2017, s. 115-157.

Michniuk A., Wspótczesna, nowomedialna(?) szkota - próba charakterystyki, [w:] Edukacyjne $i$ społeczne wyzwania rzeczywistości cyfrowej, red. A. Iwanicka, Wydawnictwo Naukowe UAM, Poznań 2007, s. 101-123.

Morańska D., Nauczyciel wobec wyzwań społeczeństwa informacyjnego, [w:] Edukacyjne $i$ społeczne wyzwania rzeczywistości cyfrowej, red. A. Iwanicka, Wydawnictwo Naukowe UAM, Poznań 2007, s. 47-56.

Ogonowska A., Wspótczesna edukacja medialna: teoria i rzeczywistość, Wydawnictwo Naukowe Uniwersytetu Pedagogicznego, Kraków 2013. 
Pyżalski J., Agresja elektroniczna i cyberbullying jako nowe ryzykowne zachowania mtodzieży, Oficyna Wydawnicza „Impuls”, Kraków 2012.

Runco M.A., To understand is to create: an epistemological perspective on human nature and personal creativity, [w:] Everyday creativity and New views of human nature. Psychological, social, and spiritual perspectives, red. R. Richards, American Psychological Association, Washington 2007, s. 91-107.

Segiet K., "Wyjść poza zastane schematy”. Znaczenie edukacji i działań modyfikujacych środowisko życia człowieka, [w:] Animacja w środowisku. O potrzebie kreowania dziatań lokalnych (teoria a praktyka społeczna), red. K. Segiet, K. Słupska, A. Tokaj, Wydawnictwo Naukowe UAM, Poznań 2017, s. 27-47.

Sroczyński W., Szkice do pedagogiki środowiskowej, Wydawnictwo Uniwersytetu Przyrodniczo-Humanistycznego w Siedlcach, Siedlce 2016.

Strykowski W., Kąkolewicz M., Ubermanowicz S., Kompetencje nauczycieli edukacji medialnej, "Neodidagmata" 29/30, Wydawnictwo Naukowe UAM, Poznań 2008, s. 55-75.

Wysocka E., Zagrożenia społeczno-kulturowe dla rozwoju młodego pokolenia, [w:] Dzieci i młodzież w niegościnnym świecie. Zagrożenia rozwojowe i spoteczne, red. E. Wysocka, Wydawnictwo Akademickie Żak, Warszawa 2012, s. 89-117.

Zbonikowski A., Społeczne oddziaływania defaworyzujące a poczucie własnej wartości dzieci i młodzieży, [w:] Psychospołeczne uwarunkowania defaworyzacji dzieci i młodzieży, red. K. Hirszel, R. Szczepanik, A. Zbonikowski, D. Modrzejewska, Wydawnictwo Difin SA, Warszawa 2010, s. 13-24.

Żeber-Dzikowska I., Teacher's and student's creativity as a challenge for the modern education, [w:] Pedagogika, red. K. Rędziński, M. Łapot, T. XXV, nr 2, Akademia im. Jana Długosza w Częstochowie, Częstochowa 2016, s. 29-38. https://fun dacja.orange.pl/aktualnosci/artykul/90-proc-nastolatkow-nie-umie-tworczo-ko rzystac-z-technologii/ [dostęp: 24.09.2018]. 